\title{
DROUGHT TOLERANCE TEST OF THREE GOGO RICE CULTIVARS USING PEG ATGERMINATION PHASE
}

\author{
Mustakim $^{\text {I) }}$, Maemunah $^{2)}$, Adrianton $^{3)}$ \\ ${ }^{1)}$ Program Of Agrotechnology, Faculty of Agriculture, University of Tadulako, Palu, \\ Email: Mustakimtrista@yahoo.co.id, \\ ${ }^{2)}$ Faculty of Agriculture, University of Tadulako, Palu, maemunah_tadulako@yahoo.co.id, adrianton78@yahoo.co.id
}

\begin{abstract}
Data in 2012 explained that Indonesia had dry land about 148 million ha (78\%) and wetland by 40.20 million ha $(22 \%)$ out of 188.20 million ha of the total land area. The variety of rice which can grow and produce well on marginal land such as gogo rice is very indispensable. This research aimed to find the gogo rice cultivars that can germinate normally in particular osmotic pressure and the tolerance limit on the drought by using PEG 6000 solution. The research was prepared with two-factor factorial design by using Completely Randomized Design. The first factor consisted of three gogo rice cultivars, namely 1 . siang, 2 . Pulut ko, and 3. roda, while the second factor consisted of four treatments, namely 1 . water as control of 2. -1 bar, 3. -2 bar, and 4. -3 bar.Thus, there were 12 combinations of treatment in which each treatment was repeated four times. In the experiment Rolled Paper placed in plastic test method was used in which there were 50 items in each experiment unit.The variable observed was potential for growth, percentage of germination, and germination rate. The research findings reveal that the three cultivars were able to germinate normally only up to -1 bar osmotic pressure, while the pulut cultivar had higher germination capacity compared with siang and roda cultivars up to -3 bar PEG 6000 osmotic pressure. Siang cultivar and -1 bar osmotic pressure gave potential for growth, germination capacity, and germination rate.
\end{abstract}

Key Words: Gogorice, Osmoticpressure. PEG.

\section{INTRODUCTION}

The rice need as one of Indonesia's main food sources continues to increase as the population increases at a rate of $2 \%$ per year (Sadimantara and Muhidin, 2012). The efforts to increase rice production to conserve rice self-sufficiency face severe challenges. Thus, increasing rice production is one option that must be done. National rice production has been focusing on irrigated rice fields, especially in Java, whereas the contribution of dry land or gogo rice spread across various islands in Indonesia is still very limited.

Dry land in Indonesia is quite large, with an estimated 60.7 million hectares or $88.6 \%$ of the land area, while the rice field area is only 7.8 million hectares or $11.4 \%$.
Data of year 2012 mentioned that Indonesia had dry land of about 148 million ha (78\%) and wetlands of 40.20 million ha (22\%) of 188.20 million ha total land area (National Coordination Agency for Spatial Planning, 2012).

Type of rice that can grow and produce well on marginal land such as gogo rice is needed. The area of gogo rice cultivation in 2011 was about 1.8 million ha. The average yield of gogo rice was still low (2.3 tons ha). This condition caused the gogo rice had not played a major role in sustaining national rice production (Deptan, 2012).

The main problem faced by gogo rice plant on marginal land is drought stress. The solution to overcome this is by producing some varieties of drought tolerant rice 
paddy. The varieties which are resistant with drought have a deep root system, a lot of rooting, larger root diameter, rooting that can penetrate deeper into the deeper layers (Rice Research Institute, 2005).

\section{RESERARCH METHODS}

Research Place and Time. This research was conducted at Seed Science and Technology Laboratory, Faculty of Agriculture, University of Tadulako, Palu. From May to August 2016.

Tools and Materials. The tools used in this research consists of: petridish,merang paper, tweezers, germination basket, germination tool, paper press tool, sprayer, ruler, yarn and stationery.

The materials used in this study consisted of: local gogo rice seed, water and Polyethylene glycol (PEG) 6000.

Research Method. This research was arranged with two factor factorial pattern using Completely Randomized Design. The first factor consisted of three gogo rice cultivars, namely K1 (Siang), K2 (Pulut $\mathrm{Ko}$ ), and K3 (Rodas). while the second factor consisted of four treatments: P0 water as control and PEG 6000 with different pressure, $\mathrm{P} 1=-1$ bar, $\mathrm{P} 2=-2$ bar, and $\mathrm{P} 3=$ -3 bar. Thus there were 12 treatment combinations, each treatment was replicated four times, so overall there were 48 experimental units. The experiments using the Rolled Paper test method were established in plastic (UKDdp) where each experimental unit had 50 eggs, so the total seeds used were 2400 grains. The observed variables were growth potential, percentage of germination, rate of germination, root length, plumula length, root dry weight, dry weight of plumula, and root volume. The data were obtained from the measurement result on each observation variables tabulated, and processed using the variance analysis. To know the effect of each treatment on the observed variables using FTest (Fisher-Test) at 95\% accuracy level, and if F-Test of each treatment showed a real or very real effect it will be followed by the test of honestly significance diffirence (HSD/HSD) at the level of $1 \%$.

\section{RESULTS AND DISCUSSION}

\section{Results}

Potential Growth.The results of the diversity analysis showed that the osmotic pressure, cultivars, and interactions had a very significant effect.

HSD test results showed that the siang cultivar had higher average potential growth values in osmotic-treated treatments $(97.5 \%)$ and significantly different from other osmotic pressures. The pulut ko cultivar had a higher potential growth value in osmotic-treated treatments $(94.5 \%)$ and was significantly different from other osmotic pressures. Roda cultivar had higher average potential growth values in osmotictreated treatments (96\%) and significantly different with other osmotic pressures.

Table1. Average value of potential growth $(\%)$.

\begin{tabular}{|c|c|c|c|c|c|}
\hline \multirow[b]{2}{*}{ K } & \multicolumn{4}{|c|}{ Osmotic preasure } & \multirow[b]{2}{*}{ HSD $1 \%$} \\
\hline & P0 & $P_{1}=-1$ bar & $P_{2}=-2$ bar & $P_{3}=-3$ bar & \\
\hline $\mathrm{K}_{1}=$ Siang & x97.5d & x91.5c & $x 68 b$ & $x 18.5 a$ & \\
\hline $\mathrm{K}_{2}=$ Pulut Ko & x94.5d & $\mathrm{x} 88.5 \mathrm{c}$ & y79b & z60.5a & 3.39 \\
\hline $\mathrm{K}_{3}=$ Roda & x96d & $\mathrm{x} 91 \mathrm{c}$ & $\mathrm{x} 71.5 \mathrm{~b}$ & y56a & \\
\hline
\end{tabular}

Description: The numbers followed by the same letter in the same row (a, b, c, d) and the same columns ( $\mathrm{x}, \mathrm{y}, \mathrm{z})$ did not differ at $\alpha=0.01$ HSD test level. 
Tabel 2. The average value of germinationpower (\%)

\begin{tabular}{|c|c|c|c|c|c|}
\hline \multirow[b]{2}{*}{ K } & \multicolumn{4}{|c|}{ Osmotic Pressure } & \multirow[b]{2}{*}{ HSD $1 \%$} \\
\hline & $\mathrm{P} 0$ & $P_{1}=-1$ bar & $P_{2}=-2$ bar & $P_{3}=-3$ bar & \\
\hline $\mathrm{K}_{1}=$ Siang & $\mathrm{x} 97.5 \mathrm{~d}$ & $\mathrm{x} 85 \mathrm{c}$ & $\mathrm{x} 55 \mathrm{~b}$ & $\mathrm{x} 11.5 \mathrm{a}$ & \\
\hline $\mathrm{K}_{2}=$ Pulut $\mathrm{Ko}$ & $\mathrm{x} 94.5 \mathrm{~d}$ & $\mathrm{x} 83 \mathrm{c}$ & y67b & $\mathrm{y} 41.5 \mathrm{a}$ & 2.89 \\
\hline $\mathrm{K}_{3}=$ Roda & x96d & $\mathrm{x} 85.5 \mathrm{c}$ & $\mathrm{x} 55.5 \mathrm{~b}$ & y41a & \\
\hline HSD 1\% & & 3.12 & & & \\
\hline
\end{tabular}

Description: The numbers followed by the same letter in the same row (a, b, c, d) and the same columns ( $\mathrm{x}, \mathrm{y}, \mathrm{z})$ did not differ at $\alpha=0.01$ HSD test level.

Table 3. Average germination rate $(\%)$.

\begin{tabular}{|c|c|c|c|c|c|}
\hline \multirow[b]{2}{*}{$\mathrm{K}$} & \multicolumn{4}{|c|}{ Osmotic Pressure } & \multirow[t]{2}{*}{ HSD 1\% } \\
\hline & $\mathrm{P} 0$ & $P_{1}=-1$ bar & $P_{2}=-2$ bar & $P_{3}=-3$ bar & \\
\hline $\mathrm{K}_{1}=$ Siang & $\mathrm{x} 3.90 \mathrm{a}$ & $\mathrm{x} 5.11 \mathrm{a}$ & $\mathrm{x} 5.06 \mathrm{a}$ & y6.46b & \\
\hline $\mathrm{K}_{2}=$ Pulut $\mathrm{Ko}$ & $\mathrm{x} 3.18 \mathrm{a}$ & $\mathrm{x} 4.56 \mathrm{~b}$ & $\mathrm{x} 4.90 \mathrm{~b}$ & $\mathrm{x} 4.66 \mathrm{~b}$ & 1.29 \\
\hline $\begin{array}{l}\mathrm{K}_{3}=\text { Roda } \\
\text { HSD 1\% }\end{array}$ & $\mathrm{x} 3.35 \mathrm{a}$ & $\begin{array}{c}\text { x3.74a } \\
1.39\end{array}$ & $\mathrm{x} 4.65 \mathrm{~b}$ & y6.30c & \\
\hline
\end{tabular}

Description : The numbers followed by the same letter in the same row $(a, b, c, d)$ and the same columns $(\mathrm{x}, \mathrm{y}, \mathrm{z})$ did not differ at $\alpha=0.01$ HSD test level.

The result of HSD test showed that in treatment without osmotic preesuresiang cultivar had higher average potential growth value $(97.5 \%)$ but not significantly different with other cultivars. Osmotic pressure -1 bar, siang cultivars had a higher average potential growth value $(91.5 \%)$ but not significantly different from other cultivars. Osmotic pressure -2 bar, pulut ko cultivar had a higher average potential growth value (79\%) and was significantly different from other cultivars. The osmotic pressure of -3 bar, the kout cultivar had a higher average potential growth value $(60.5 \%)$ and was significantly different from that of other cultivars.

Germination Power.The results of variance analysis showed that the osmotic, cultivar, and interaction pressure were very significant.

The HSD test results in Table 2. showed that, the siang cultivars had a higher mean germination rate on a treatment without osmotic pressure $(97.5 \%)$ and were significantly different from other osmotic pressures. The pulut ko cultivar had a higher average germination rate in osmotic pressure treatment $(94.5 \%)$ and was significantly different from other osmotic pressures. The roda cultivar had a higher average germination rate on a treatment without osmotic pressure $(96 \%)$ and was significantly different from other osmotic pressures.

The result of HSD test in Table 2. showed that in treatment without osmotic pressure to siang cultivar had higher average germination value $(97.5 \%)$ but not significantly different with other cultivars. The osmotic pressure of bar-1, roda cultivars had higher mean germination $(85.5 \%)$ but not significantly different from other cultivars. The osmotic pressure of the bar-2, the pulut ko cultivar had a higher average germination rate $(67 \%)$ and was significantly different from that of the other cultivars. The osmotic pressure of -3 bar, pulut kocultivar had a higher average germination value $(41.5 \%)$ and was significantly different from that of the afternoon cultivars, but not significantly different from the roda cultivars. 
Germination rate. The results of the variance analysis showed that the osmotic pressure, cultivars, and interactions had a very real effect.

The HSD test results showed that siang cultivars had a faster rate of germination in the osmotic pressure treatment $(3.90 \%)$ and significantly differed from the osmotic pressure of -3 bar, but not significantly different from the osmotic pressure -1 and 2 bar. The pulut kocultivar had a faster rate of germination rate at osmotic pressure treatment (3.18\%) and was significantly different from other osmotic pressures. The roda cultivar had a faster germination rate in the osmotic pressure treatment $(3.35 \%)$ and was significantly different from the osmotic pressure of -2 and -3 bar, but not significantly different from the osmotic pressure of -1 bar.

The result of HSD test showed that in the treatment without osmotic pressure of pulut ko cultivar that the coefficient had faster average germination rate $(3.18 \%)$ but not significantly different with other cultivars. The osmotic pressure of bar-1, roda cultivars had an average rate of faster germination rate $(3.74 \%)$ but was not significantly different from that of other cultivars. Osmotic pressure -2 bar, roda cultivar had average value of faster germination rate $(4.65 \%)$ but not significantly different with other cultivars. The osmotic pressure of -3 bar, pulut ko cultivar had the average value of faster germination rate $(4.66 \%)$ and was significantly different from other cultivars.

\section{Discussion}

The results showed that the interaction between cultivars and osmotic pressure had significant effect on growth potential observation variables, germination power germination rate, root length, root dry weight, plumula dry weight and root volume, whereas in length observation variables of plumula's interaction was only significant .

The higher of osmotic pressure used then the result willbe decrease. This was because the higher osmotic pressure used, the more concentrated solution and more water binding, so the seeds were difficult to absorb water that willbe used in metabolic processes that causeyield decrease and germination rate increase

This was consistent with the statement of Verslues et al. (2006) suggesting that the more concentrated PEG concentrations the more sub ethylene subunits bind the water, the more difficult it is to absorb water the plants cause drought stress. PEG induces germination inhibition because it is associated with osmotic stress (Sidari et al., 2008). Meanwhile, according to La Ode Afa, et al (2012) PEG dissolved in water causes water molecules $(\mathrm{H} 2 \mathrm{O})$ will be attracted to oxygen atoms in subunitethylene oxide through hydrogen bonds so the water potential decreases.

Mumford and Brett (1982) said that the addition of PEG into the germination solution cause the retrieval ofwater for germination and the seeds retained adequate water content to prevent drought. The seed cell membrane is semi permeable, it means it allows the water molecules to enter but prevents large molecules such as PEG into the seed cells.

According to Sudharmawan, A. (2010), the solution of PEG 6000 with concentrated concentration will decrease the germination rate. At the osmotic pressure of PEG 6000 - 2 bar of rice varieties with high tolerance to dryness did not give a significant effect on the growth rate. This was in line with Sadjad's (1993) statement, a fast-growing seed has better ability to cope with sub optimum field conditions such as drought stress.

The three cultivars used gave different results even with the same osmotic pressure. This was because every cultivar had different water-absorbing ability, because the water absorbed will be used by seed in metabolic process.

This was in accordance with Sadjad's (1980) statement that the chemical composition of seeds, seed skin permeability and the amount of water both 
in liquid and gas form affects the process of seed imbibition. The difficulty of this imbibition process is what causes the difference between the seeds of one with the other seeds

In metabolic activity, the gibberellin produced by the embryo transransfered to the aleuron layer resulted in the amylase enzyme-. Furthermore, the enzyme enters the food reserves and catalyzes the process of altering the food reserves of starch into sugars so as to produce useful energy for cell activity and growth (Bewley 1997)

\section{CONCLUSION AND SUGGESTION}

\section{Conclusion}

From the results of the discussion above it can be concluded:
1. Siang cultivars and osmotic pressure -1 bars provided the potential growth, germination and rate of germination.

2. Third cultivars can only normal germinate to osmoticum pressure -1 bar, but pulut ko cultivar had higher germination than siang and roda cultivars until -3 bar PEG 6000osmotic pressure

3. Seeds can germinated normally at -1 barosmotic pressure

\section{Suggestion}

In the development of gogo rice on dry land, there is a need for further research on drought tolerant rice to the drought, so that the information obtained can be useful especially in the field of agriculture and become a protection for germplasm.

\section{REFERENCES}

Bewley, J.D. (1997). Seed germination and dormancy. The Plant Cell, 9, 1055-1066.

BKPRN,2012. Buletintataruang BKPRN, Badan koedinasi penataan ruang nasional. Menata kawasan hutan dan mempertahankan lahan pertanian. http:// www.pu.go.id/ search? Lahan 20\% kritis. Diakses pada tanggal 08 Juli 2016

Deptan, 2012. Basis data statistic pertanian. http://aplikasi.deptan.go.id/ bdsp/newind.asp. Diakses tanggal 08 Juli 2016

Balai Penelitian Tanaman Padi. 2005. Padi Gogo dan Pola Pengembangannya. Departemen Pertanian

La Ode Afa,Bambang S. Purwoko, Ahmad Junaedi, Oteng Haridjaja dan Iswari S. Dewi. 2012. Pendugaant oleransi padi hibrida terhadap kekeringan dengan Polyetilenglikol (PEG). $J$. Agrivigor 11(2): 292-299, Mei-Agustus 2012; ISSN 1412-2286

Mumford, P.M. and A.C. Brett. 1982. Conservation of cacao seed. Trop.Agriculture, 59 (4) : 303307.

Sadimantara, G.R dan Muhidin. 2012. Karakterisasi Morfologi Ketahanan Kekeringan Plasma Nutfah Padi Gogo Lokal Asal Sulawesi Tenggara. Jurnal Agroteknos 2(2) : 81-92

Sadjad, S. 1980". Panduan Pembinaan Mutu Benih Tanaman Kehutanan di Indonesia. Direktorat Jenderal Kehutanan dan Lembaga Afiliasi.

Sadjad, S. 1993. Dari Benih Kepada Benih. Jakarta: Grasindo.

Sidari, M., C. Mallamaci, and A. Muscolo. 2008. Drought, salinity and heat differently affect seed germination of Pinuspinea. J Forest Res 13:326- 330 
Sudharmawan., A. 2010. Analisis Rerata Generasi Hasil Persilangan Dua Varietas Padi Tahan Terhadap Cekaman Kekeringan. Journal Crop Agro 3(1):65-70.

Verslues, P.E., M. Agarwal, K.S. Agarwal. 2006. Methods and concepts in quantifying resistance to drought, salt and freezing, abiotic stress that affect plant water status. Plant J.45:523-53. 